\title{
INFLUENCE OF FOUNTAIN SOLUTION TO THE CORROSION OF MACHINE PARTS IN OFFSET PRINTING
}

\author{
DRAGCEVIC, K[resimir] \& LOVRECEK, M[laden]
}

\begin{abstract}
With introducing the environmentally acceptable fountain solution in printing systems, the effect of corrosion of machine elements becomes more aggressive, unknown and unpredictable, which partly or completely disables long-term exploitation and amortization of printing machines. In addition, the electrochemical potentiodynamic measurements were carried out with the direct current and the method of linear polarization and Tafel's extrapolation, by which the corrosion parameters were determined: corrosion potential, corrosion current density, polarization resistance cathodic and anodic inclination of Tafel's lines, as well as the corrosion rate. This article gives an insight into a different principle of corrosion processes in conventional and environmentally acceptable fountain solutions wetting solution, and contributes to more precise predictions of spending offset machines that use organic solvents.
\end{abstract}

Keywords: corrosion, offset printing, fountain solution, linear polarization, Tafel's extrapolation

\section{INTRODUCTION}

Corrosion is every an unintentional destruction of construction materials, most commonly caused by physical and chemical agents. In the use of printing machines wearing is to a great extent caused by friction between machine parts, as well as under the influence of agents with which they are in contact (lubricants, condensed water, used solutions, washing agents etc [1].

Parts of the printing machines are built of different kinds of steel, depending on mechanical-chemical conditions to which they are exposed during the printing process. Additionally, each manufacturer for machine parts uses specific, mainly patent protected steels or steel alloys. From the corrosion aspect, the offset printing system - as dominant printing technique - is specific because machine parts during the operation come in contact with agents of different physicochemical characteristics. According to available data, the fountain solution is most corrosive among them, mostly based on alcohols, hydrophilization salts, salts for regulation of conductivity and hardness [2]. It is difficult to determine the grounds of corrosion processes developing under such a complex conditions; in this investigation, therefore, the steel was exposed to the solutions of systematically changed composition in order to follow the influence of certain parameters on corrosion processes[3].

All parts of offset printing machines are of high quality production, with very low allowed tolerances; therefore, even micrometric changes will significantly influence the quality of prints. Lowest traces of corrosion products in bearings of cylinders will cause vibrations of machine parts, while traces of corrosion products on cylinders (base, offset and printing) will cause sliding higher than expected.

In order to follow separately the influence of fountain solutions on corrosion, the laboratory steel (DIN Ust. 12) was used. According to the available data from the manufacturer, the steel used is nearly of the same composition as the one used for construction of cylinders to which the fountain solution is in contact [4]. With a great degree of probability, it can be assumed that the rate of corrosion described in this paper is - the same as on steels used for the construction of printing machines. Primary goal of this investigation was to give a contribution to the interpretation of corrosion processes of the steel under the influence of different fountain solutions used in offset printing.

\section{THEORETICAL BACKGROUND}

\subsection{Fountain Solution}

Basic role of the fountain solution in the offset printing process is oleofobisation of non-printing areas on the printing forms. Ink, which is subsequently deposited, is bound to printing surfaces only, and together with the fountain solution is under pressure, over rubber blanket transferred onto the printing substrate, in most cases paper [5].

Besides its basic role, fountain solution passing through the machine and mixing with the ink, enables define oxypolymerization, defines viscosity, maintaining the temperature of the machine by evaporating, while corrosion inhibitors prevent corrosion of the machine parts. Passing of sheets or web through the machine, surface coating of the paper - due to the friction between the offset and printing cylinders, as well as to the chemical dissolution - enter the fountain solution on the offset cylinder. Subsequently, due to the rotation of machine parts it reaches the remaining cylinders, dampening system and finally, the fountain solution tank. Fountain solution, polluted with dissolved paper coatings, particles of fillers and paper fibers, traces of pigments etc. has changed properties necessary for printing, thus becoming essentially more corrosive medium.

In conventional alcohol-based dampening systems 2propanole is primarily used for decreasing the surface tension of the fountain solution; however, it is also wellknown corrosion inhibitor [6]. 2-propanole alcohol is very volatile and is considered as a harmful primary and secondary atmosphere pollutant. According to the available data, in conventional alcohol-based dampening systems, to a great extent the effect of corrosion was not 
generated by the fountain solution [7]. In such systems, corrosion and wearing of machine parts are an inevitable effect, but their rate is known and predictive.

In contemporary offset printing systems of environmentally friendly fountain solutions are developed, which are only to a certain extent influencing the environment[8]. These concentrates are aggressive media, but observed from the technological aspect, more significant problem is that the corrosion rate in such system is unknown and unpredictable. It is therefore necessary in further development of offset printing to investigate the influence of parameters of fountain solutions (chemical, electrochemical, physicochemical, and mechanical) on corrosion of the machine parts [9].

\subsection{Method with the direct current (linear polarization and Tafel's extrapolation)}

The method of Tafel extrapolation is based on a Butler-Volmer equation (1) which is the fundamental relationship in electrochemical kinetics.

$$
\mathrm{j}=\mathrm{j}_{+}-\left|\mathrm{j}_{-}\right|=\mathrm{j}_{0}\left\{\exp \left[\frac{(1-\alpha) z \mathrm{~F} \eta_{\mathrm{e}}}{\mathrm{RT}}\right]-\exp \left[-\frac{\alpha z \mathrm{~F} \eta_{\mathrm{e}}}{\mathrm{RT}}\right]\right\}
$$

With Tafel extrapolation of anodic and catodic slopes, conducted for a wider range of potential $\left(\mathrm{E}=\mathrm{E}_{\mathrm{cor}} \pm\right.$ $250 \mathrm{mV}$ ), is posible to determine a corrosion potential $\left(\mathrm{E}_{\mathrm{cor}}\right)$ and a corrosion current density $\left(\mathrm{j}_{\text {cor }}\right)$. Corrosion potentials, Tafel constants $\left(\beta_{\mathrm{a}}\right.$ and $\beta_{\mathrm{c}}$ ) and polarization resistance can be determined from voltammograms obtained by potential-dynamic recordings in different mediums.

From Butler-Volmer equation (1), Stern and Geary developed equation (2) on which the method of linear polarization is based. With this method corrosion current can be determined if polarization resistance is known.

$$
j_{\text {cor }}=\frac{\beta_{a} \beta_{c}}{2,303\left(\beta_{a}+\beta_{c}\right)} \frac{1}{R_{p}}=\frac{B}{R_{p}}
$$

Where:

$\mathrm{j}_{\text {cor }}$ - corrosion current density $\left(\mu \mathrm{A} \mathrm{cm}^{-2}\right)$,

B - Stern-Geary constant (V),

$\mathrm{R}_{\mathrm{p}}$ - polarization resistance,

$\beta_{\mathrm{a}}$ - slope of the anodic Tafel reaction, when plotted on base 10 logarithmic paper in V/decade and $\beta_{c}$ - slope of the cathodic Tafel reaction when plotted on base 10 logarithmic paper in V/decade.

Polarization resistance is determined experimentally (for potential close to $\mathrm{E}_{\mathrm{cor}}$ ) with equation (3):

$$
R_{p}=\frac{\Delta E}{\Delta j}
$$

Using both methods (Tafel extrapolation and linear polarization) of current density values obtained corrosion rate was calculated using the formula (4):

$$
C R=K j_{\text {cor }} \frac{M}{z \rho}
$$

Where:

$\mathrm{CR}$ - corrosion rate $\left(\mathrm{mm} \mathrm{yr}^{-1}\right)$,
$\mathrm{K}$ - constant from Faraday's Equation Rate, $\left(3.2710^{-3}\right.$

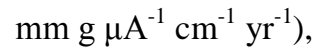

$\mathrm{j}_{\text {cor }}$ - corrosion current density $\left(\mu \mathrm{A} \mathrm{cm}^{-2}\right)$,

$\mathrm{M}$ - the atomic weight of the element $\left(\mathrm{M}_{\mathrm{Fe}}=55.845\right)$,

$\mathrm{Z}$ - the number of electrons required to oxidize an atom of the element in the corrosion process ( in the observed system is $z=2$ ) and $\rho$ - density in $\mathrm{g} \mathrm{cm}^{-3}$ ( steel $\rho=7.861 \mathrm{~g} \mathrm{~cm}^{-3}$ ).

Both methods of potentiodynamic polarization have limitations because both of them only give insight into the mechanisms of corrosion caused by the chemically steady conditions. In usual circumstances machine parts rotates which has a different influence on corrosion. However, based on experience gained from previous studies, the degree of corrosion in real systems is directly correlated with the degree of corrosion determined, with the potentiodynamic polarization methods, in laboratory conditions.

\section{EXPERIMENTAL}

\subsection{Measuring methods}

For investigation the electrochemical measurements were carried out with the direct current methods of linear polarization and Tafel's extrapolation. The measurements also were conducted with potentiostat/galvanostat Versa STAT 3 manufactured by Matek-EG\&G Princeton Applied Research. Obtained measurements were processed with VersaStudio software.

All tests were conducted in a standard sealed electrochemical cell with auxiliary electrode made of pressed carbon and saturated calomel reference electrode (SCE) which was, with luggin capillary, brought near the working electrode. All potential values in this study were measured and will be shown in relation to the value of the reference electrode. The surface of the sample is sealed in the holder of the working electrode with a teflon ring so that the area of exactly $1 \mathrm{~cm}^{-2}$ of the sample is exposed to the solution.

In determining the polarization resistance by linear polarization, the potential varied in range of $-20 \mathrm{mV}$ to $+20 \mathrm{mV}$ from the value of open circuit potential $\left(\mathrm{E}_{\mathrm{ocp}}\right)$. Tafel's extrapolation is implemented in a wide range of potential values, in range of $-200 \mathrm{mV}$ to $+200 \mathrm{mV}$ of the value of open circuit potential $\left(\mathrm{E}_{\mathrm{ocp}}\right)$. The potential value was increased by $0.5 \mathrm{mV}$ each 2 seconds, thus, the scan rate in potential was $0.25 \mathrm{mV} \mathrm{s}^{-1}$

\subsection{Treatment of the electrodes}

In this investigation the laboratory carbon steel was used DIN Ust $12\left(\mathrm{C}_{\max } 0.12 \%, \mathrm{Mn}_{\max } 0.50 \%, \mathrm{P}_{\max } 0.04 \%\right.$, $\mathrm{S}_{\max } 0.04 \%$ ), with electrodes cut out from a single plate of area cca $1 \mathrm{~m}^{2}$ and $0.7 \mathrm{~mm}$ thick. Immediately after treatment the electrode was left in contact with air to form a natural oxide layer, it is then placed into a holder and immersed in the solution.

Surface of specimens was treated with grinding paper T 400 and $\mathrm{T} 800$, furthermore highly polished with the polishing paste. After mechanical treatment, specimens were for 5 minutes immersed into undiluted acetone, shortly immersed in water and for 10 seconds decapitated in $10 \%$ water solution of sulphuric acid. After two 
minutes of washing in distilled water and drying in the air, specimens were immersed into the electrolyte. Uniformity of surface treatments was checked with the spectrophotometer and on all repared specimens the same spectral re-emission was recorded.

\subsection{Preparation of solutions}

In real printing processes demineralized and deionized water is used to prepare the fountain solution. It can be assumed that the components remaining in the water after demineralization and deionization do not influence significantly corrosion processes; in this investigation, therefore, freshly opened distilled water produced by INA-Maziva d.d according to ISO 9001, ISO 14001 and OHSAS 18001, as to exclude influence of starting parameters of water (firstly its $\mathrm{pH}$ value) on corrosion processes.

First electrolyte (herein after referred as to E1) is a conventional fountain solution with the addition of 2propanole alcohol, which did not show significant corrosion phenomena in real printing conditions. $500 \mathrm{ml}$ of the solution was prepared, containing $3 \%$ of alcohol buffer "Fountain solution Blue 3300" prod. Vegra and $3 \%$ of 2-propanole.

Second electrolyte (herein after referred as to EH2) a conventional fountain solution with the addition of 2 propanole alcohol with addition to the regulation of hardness. $500 \mathrm{ml}$ of the solution was prepared, containing $3 \%$ of alcohol buffer "Fountain solution Blue 3300 " prod. Vegra, 3\% of 2-propanole and $0.5 \%$ addition to the regulation of hardness "Aquadot-Hardening Agent 250010 - VP9113" prod. Vegra. Thus prepared solution is used in conventional offset printing systems.

Third electrolyte (herein after referred as to E3) is an ecologic solution intended for non-alcoholic dampening, showing corrosion in real printing conditions. $500 \mathrm{ml}$ of the solution was prepared, containing $3 \%$ of the buffer “Alco-Damp RED 3232/870 Zi dH N" prod. Vegra.

Fourth electrolyte (herein after referred as to EH4) is an ecologic solution intended for non-alcoholic dampening with addition to the regulation of hardness. $500 \mathrm{ml}$ of the solution was prepared, containing 3\% of the buffer "Alco-Damp RED 3232/870 Zi dH N" prod. Vegra and $0.5 \%$ addition to the regulation of hardness "Aquadot-Hardening Agent 250010 - VP9113" prod. Vegra. Thus prepared solution used environmentally friendly offset printing systems.

Deaeration of electrolyte was carried out by nitrogen 5.0 (>99.999 vol\% $\mathrm{N}_{2}$ ).

\section{RESULTS AND DISCUSSION}

Figure 1 shows the curves of linear polarization, and in Table 1 values obtained using linear polarization of steel in solutions: E1, EH2, E3 and EH4 are shown. Corrosion parameters of the initial fountain solution without contamination were compared with each other. Depending on the parameters of water used to prepare the fountain solution, basic conventional alcoholic or ecological concentrate of the fountain solution and the solution for regulation of hardness is added. In most modern systems for the preparation of the fountain solution, demineralised and / or deionized water is used [10].
Thus, according to manufacturer's instructions, in such systems is usually added a solution for the regulation of hardness. In both observed systems the solution for the regulation of hardness increases the corrosion rate. In accordance with previous studies, the values of corrosion rate of steel in the conventional alcoholic fountain solution are larger than the value obtained in organic solution, which indicates that the solution is present in the organic corrosion inhibitor [11].

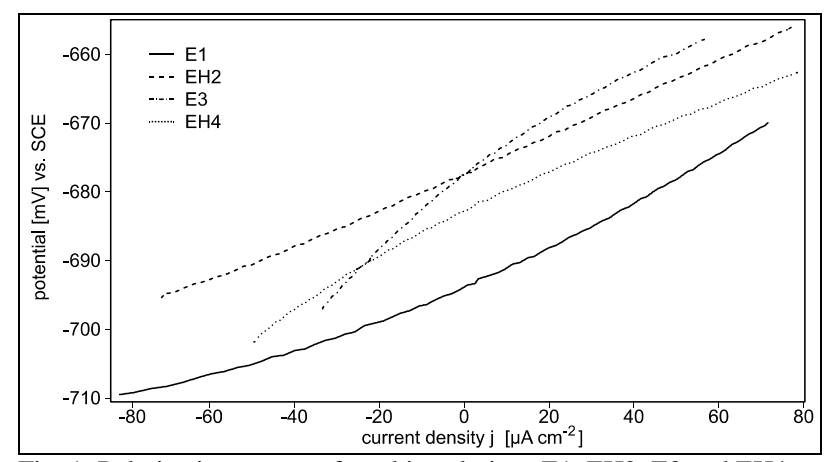

Fig. 1. Polarization curves of steel in solutions E1, EH2, E3 and EH4

\begin{tabular}{|c|c|c|c|c|}
\hline solution & $\mathrm{E}_{\text {cor }} / \mathrm{mV}$ & $\mathrm{j}_{\text {cor }} / \mu \mathrm{A} \mathrm{cm}^{-2}$ & $\mathrm{R}_{\mathrm{p}} / \Omega \mathrm{cm}^{2}$ & $\mathbf{C R} / \mathbf{m m} \mathbf{~ y r}^{-1}$ \\
\hline E1 & -692 & 75.134 & 289 & $\mathbf{0 . 8 7 5}$ \\
\hline EH2 & -676 & 81.165 & 267 & $\mathbf{0 . 9 4 5}$ \\
\hline E3 & -677 & 47.913 & 453 & $\mathbf{0 . 5 5 7}$ \\
\hline EH4 & -683 & 71.812 & 302 & $\mathbf{0 . 8 4 2}$ \\
\hline
\end{tabular}

Tab. 1. Corrosion parameters determined by the method of linear polarization for solutions E1, EH2, E3 and EH4

Figure 2 shows the linear polarization curves, and Table 2 values obtained using linear polarization of steel in deaerated solutions: E1/N, EH2/N, E3/N and EH4/N. Deaeration of conventional alcoholic solution of corrosion rate is higher. On this higher rate of corrosion greater impact has increased evaporation of 2-propanol during deaeration than reduction of the oxygen concentration in the electrolyte. With the deaeration of ecological solutions with added hardness corrosion rate is lower.

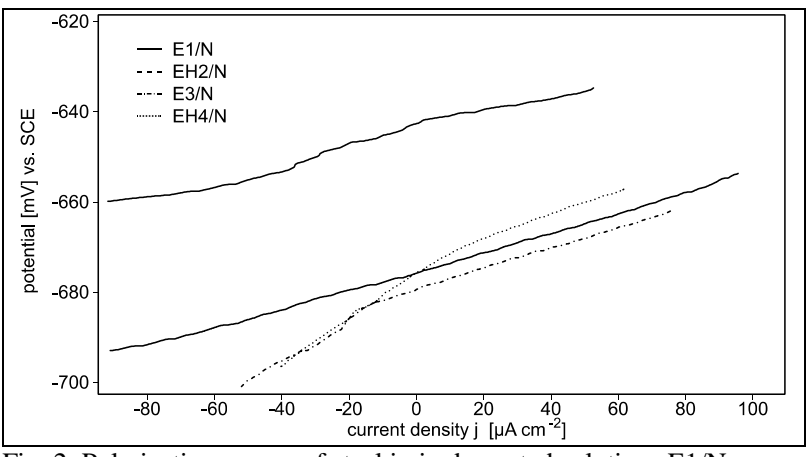

Fig. 2. Polarization curves of steel in in deaerated solutions E1/N, $\mathrm{EH} 2 / \mathrm{N}, \mathrm{E} 3 / \mathrm{N}$ and $\mathrm{EH} 4 / \mathrm{N}$

\begin{tabular}{|c|c|c|c|c|}
\hline solution & $\mathrm{E}_{\text {cor }} / \mathrm{mV}$ & $\mathrm{j}_{\text {cor }} / \mu \mathrm{A} \mathrm{cm}^{-2}$ & $\mathrm{R}_{\mathrm{p}} / \Omega \mathrm{cm}^{2}$ & $\mathbf{C R} / \mathbf{m m ~ y r}^{-1}$ \\
\hline $\mathrm{E} 1 / \mathrm{N}$ & -643 & 99.413 & 218 & $\mathbf{1 . 1 5 7}$ \\
\hline $\mathrm{EH} 2 / \mathrm{N}$ & -675 & 101.585 & 213 & $\mathbf{1 . 1 8 2}$ \\
\hline $\mathrm{E} 3 / \mathrm{N}$ & -681 & 75.181 & 289 & $\mathbf{0 . 8 8 1}$ \\
\hline $\mathrm{EH} 4 / \mathrm{N}$ & -676 & 57.602 & 377 & $\mathbf{0 . 6 7 0}$ \\
\hline
\end{tabular}

Tab. 2. Corrosion parameters determined by the method of linear polarization for deaerated solutions E1/N, EH2/N, E3/N and EH4/N 
Figure 3 shows the potenciodynamic polarization curves, and Table 3 shows the values obtained by Tafel extrapolation of the steel in the solutions: E1, EH2, E3 and EH4. The values of corrosion potential and current density are consistent with the values obtained using linear polarization. The values of corrosion rate for the system of ecological solutions are lower than in alcoholic solution system. With the addition of the solution for the regulation the hardness values of corrosion rate are higher for both systems.

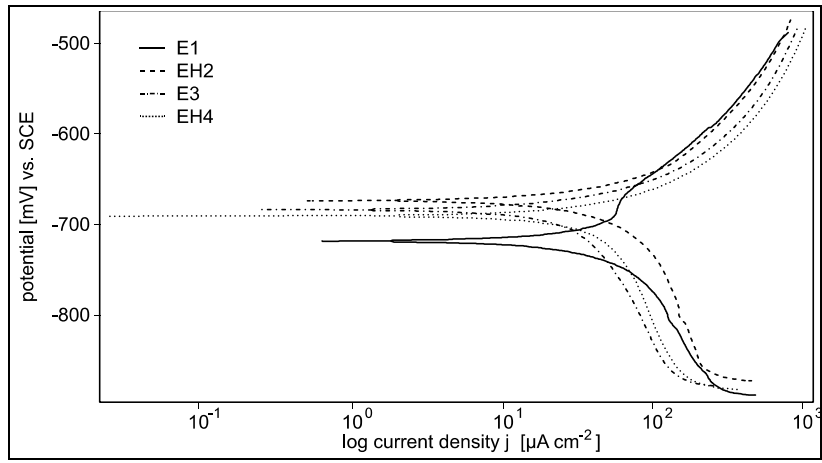

Fig. 3. Polarization curves of steel in solutions E1, EH2, E3 and EH4

\begin{tabular}{|c|c|c|c|c|c|}
\hline solution & $\begin{array}{c}-\beta_{\mathrm{c}} \\
{[\mathrm{mV} / \mathrm{dec} \text { ede }]}\end{array}$ & $\begin{array}{c}\beta_{\mathrm{a}} \\
{[\mathrm{mV} / \mathrm{dec} a d e]}\end{array}$ & $\begin{array}{c}\mathrm{E}_{\mathrm{cor}} \\
{[\mathrm{mV}]}\end{array}$ & $\begin{array}{c}\mathrm{j}_{\mathrm{cor}} \\
{\left[\mu \mathrm{Am}^{-2}\right]}\end{array}$ & $\begin{array}{c}\mathbf{C R} \\
{\left[\mathbf{m m ~ y r}^{-1}\right]}\end{array}$ \\
\hline E1 & 226 & 207 & -721 & 70.264 & $\mathbf{0 . 8 1 8}$ \\
\hline EH2 & 331 & 103 & -674 & 85.611 & $\mathbf{0 . 9 9 6}$ \\
\hline E3 & 521 & 64 & -684 & 45.893 & $\mathbf{0 . 5 3 4}$ \\
\hline EH4 & 668 & 94 & -690 & 72.230 & $\mathbf{0 . 8 4 1}$ \\
\hline
\end{tabular}

Tab. 3. Corrosion parameters determined by the method of Tafel extrapolation for solutions E1, EH2, E3 and EH4

Figure 4 shows the potenciodynamic polarization curves, and Table 4 shows the values obtained by Tafel extrapolation of the steel in deaerated solutions: E1/N, $\mathrm{EH} 2 / \mathrm{N}, \mathrm{E} 3 / \mathrm{N}$ and EH4/N. Corrosion parameters obtained indicate that the initial solution after deaeration become aggressive corrosive media. This phenomenon could be attributed to the evaporation of the inhibitor component of initial electrolyte.

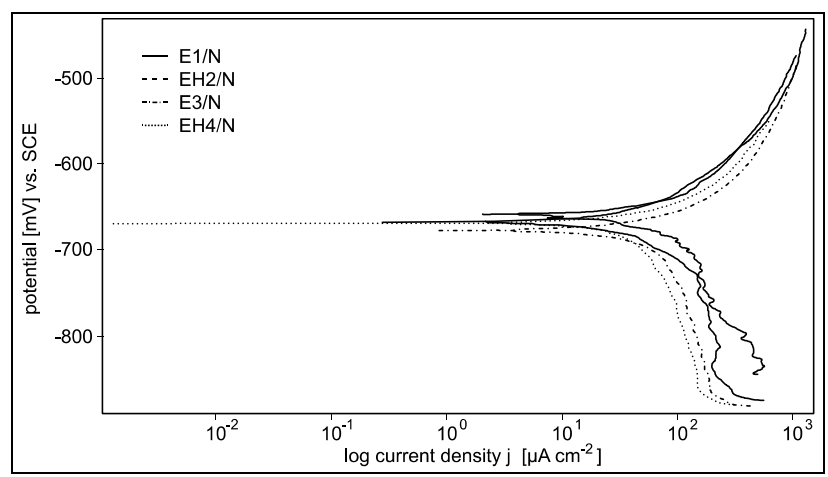

Fig. 4. Polarization curves of steel in deaerated solutions E1/N, EH2/N, $\mathrm{E} 3 / \mathrm{N}$ and $\mathrm{EH} 4 / \mathrm{N})$

\begin{tabular}{|c|c|c|c|c|c|}
\hline solution & $\begin{array}{c}-\beta_{\mathrm{c}} \\
{[\mathrm{mV} / \text { decade }]}\end{array}$ & $\begin{array}{c}\beta_{\mathrm{a}} \\
{[\mathrm{mV} / \mathrm{decade}]}\end{array}$ & $\begin{array}{c}\mathrm{E}_{\text {cor }} \\
{[\mathrm{mV}]}\end{array}$ & $\begin{array}{c}\mathrm{j}_{\text {cor }} \\
{\left[\mu \mathrm{Am}^{-2}\right]}\end{array}$ & $\begin{array}{c}\mathbf{C R} \\
{\left[\mathbf{m m ~ y r}^{-1}\right]}\end{array}$ \\
\hline E1/N & 238 & 116 & -658 & 123.061 & $\mathbf{1 . 4 3 2}$ \\
\hline EH2/N & 278 & 166 & -667 & 116.623 & $\mathbf{1 . 3 5 7}$ \\
\hline E3/N & 177 & 89 & -676 & 86.424 & $\mathbf{1 . 0 0 6}$ \\
\hline EH4/N & 371 & 74 & -668 & 56.777 & $\mathbf{0 . 6 6 1}$ \\
\hline
\end{tabular}

Tab. 4. Corrosion parameters determined by the method of Tafel extrapolation for deaerated solutions E1/N, EH2/N, E3/N and EH4/N

\section{CONCLUSIONS}

From the conducted investigation, the following can be concluded:

The effect of corrosion is imminent in the processes of graphic reproduction, especially in offset printing, where certain machine parts are exposed to the influence of the fountain solution. Corrosion can affect operation of some systems, which - as a consequence - has problems in function of the printing press and poor quality of the prints.

In contact with real fountain solutions, with the added corrosion inhibitor, the corrosion rate of steel samples was significantly decreased.

From the results obtained in research and compared with observations under real terms of printing process it can be concluded that the ecologic fountain solution becomes chemically more aggressive only in presence of the dissolved compounds from printing inks, paper and other solutions used during the printing process.

The test system deaeration fountain solutions substantially increases the degree of corrosion, which can easily be attributed to evaporation of volatile components from the initial solution.

It was affirmed that the ecologic fountain solution in the entry state, without contamination, is less corrosive medium than the conventional alcohol solutions.

\section{REFERENCES}

[1] Stupnišek-Lisac, E. (2007). Corrosion and protection of a construction matherials, Korozija $i$ zaštita konstrukcijskih materijala, FKIT, ISBN 978-953-6470-31-0, Zagreb

[2] Kipphan, H. (2001). Handbook of Print Media-Technologies and Production Methods, Springer-Verlag, ISBN 3-540-67326, Berlin

[3] Marošević, G. \& Bauer, G. (1991). Mehanička svojstva gumenih navlaka u ofsetu. Acta Graphica, Vol.. 3, 129.-138, ISSN 03534707

[4] Lovreček, M. (1990). Funkcija otopine za vlaženje u ofsetnom tisku. Acta Graphica, Vol. 2, 139-141,ISSN 0353-4707

[5] Baudin, G. (1999). Acido-basic theory and offset surface, Acta Graphica, Vol. 11, 113-127, ISSN 0353-4707, Zagreb

[6] Rauch, W. (1999). Investigations into the Reduction or Replacement of 2-propanol in Dempening Solutions for Offset Printing, Munich, Research Report No. 32.103 of FOGRA institute, FOGRA Forschungsgesellschaft Druck e.V., 1-11

[7] Dragčević, K.; Lovreček, M. \&; Dragčević, Đ. (2005) Investigation of corrosion in print production, Proceedings of the IARIGAI 32, International Iarigai Research Conference, 3-7 September 2005, Finland, ISBN 953- 7292-01-0, Enlund, N.(Ed.), 251-260, IARIGAI, Porvoo

[8] Dragčević, K. \& Lovreček, M. (2010). Istraživanje korozije u sustavima ofsetnog tiska, Proceedings PDC conference 2010, 6 . 9. October 2010, Hrvatska, ISBN 9789537644062, Mikota M. (Ed), 166-175, University of Zagreb, Faculty of Graphic Arts, Senj

[9] Aromaa, J. \& Klarin, A. (1999). Materials, Corrosion Prevention and Maintenance, Papermaking Science and Tehnology, University of Tehnology, ISBN 952-5216-15-2, Helsinki,

[10] Walenski, W. (1991). Offset Druck, Polygraph-Handbuch, ISBN 3-8764,1-246-3, Frankfurt am Main

[11] Dragčević, K. (2010). Istraživanje korozije u procesima grafičke reprodukcije, Ph.D. Dissertation, Faculty of Grafhic Arts, University of Zagreb, Zagreb, Hrvatska 